\title{
Full utilization of nutrients in rice straw by integrating mushroom cultivation, biogas production, and fertilizer use
}

\author{
Wenbo Huang ${ }^{1}$, Akiber Chufo Wachemo ${ }^{1,2}$, Hairong Yuan ${ }^{1}$, Xiujin $\mathrm{Li}^{\mathrm{i}^{*}}$ \\ (1. Department of Environmental Science and Engineering, Beijing University of Chemical Technology, Chaoyang District, \\ Beijing 100029, China; \\ 2. Faculty of Water Supply and Environmental Engineering, Arba Minch University, P.O.Box 21, Arba Minch, Ethiopia)
}

\begin{abstract}
This study proposed an integrated process of Pleurotus ostreatus cultivation, anaerobic digestion of spent mushroom substrate (SMS), and fertilizer value evaluation of digestate for achieving multiple products and full utilization of nutrients in rice straw. The results showed that the cultivated mushroom yield from rice straw was $401 \mathrm{~g} / \mathrm{kg}$ TS. Biomethane yield obtained from anaerobic digestion of SMS was $133.0 \mathrm{~mL} / \mathrm{g} \mathrm{VS}$. The fertilizer value of the SMS based digestate reached the national standard of fertilizers from organic sources in China. Substance conversion of rice straw during the integrated process revealed that the process could achieve the full utilization of nutrients in the substrate. Energy assessment indicated that the process had the viability to be applied. Therefore, this study provided a feasible strategy to set up a complete recycling agricultural ecosystem.
\end{abstract}

Keywords: rice straw, Pleurotus ostreatus, anaerobic digestion, fertilizer value, full utilization DOI: $10.25165 /$ j.ijabe.20191204.4658

Citation: Huang W B, Wachemo A C, Yuan H R, Li X J. Full utilization of nutrients in rice straw by integrating mushroom cultivation, biogas production, and fertilizer use. Int J Agric \& Biol Eng, 2019; 12(4): 174-183.

\section{Introduction}

China is one of the biggest crop-producing countries, which contributes $28.7 \%$ of the total global rice output. In 2015 statistics showed that the total rice straw yield was over 230 million tons, which made China as one of the most leading countries in terms of rice straw resource in the world ${ }^{[1]}$. However, until today the traditional rice straw handling practices in China are open field burning and being throwing aside have been often carried out after harvest season. Such practices led to pose environmental and health threats, in addition to the large sum of energy and nutrient losses.

The common ways of rice straw utilization in China include papermaking, compost, and production of livestock forage $\mathrm{e}^{[2,3]}$. However, the product value and energy recovery from rice straw through those methods were relatively low. On the other hand, the rice straw has been used in recent years for biological processes like mushroom cultivation and anaerobic digestion (AD) to generate value-added products such as mushroom and biomethane, respectively.

Cultivation of mushroom could be considered as an economically feasible way for converting the rice straw into protein-rich food ${ }^{[4]}$. Additionally, the spent mushroom substrate (SMS) provided an alternative substrate for microorganisms in the anaerobic environment, because mushroom cultivation improved

Received date: 2018-09-17 Accepted date: 2019-07-05

Biographies: Wenbo Huang, $\mathrm{PhD}$ candidate, research interests: biomass waste and bioenergy, Email: iorihwb@163.com; Akiber Chufo Wachemo, PhD, research interests: biomass waste and bioenergy, Email: akiberchufo@, yahoo.com; Hairong Yuan, $\mathrm{PhD}$, Associate Professor, research interests: biomass waste and bioenergy, Email: yuanhairong75@163.com.

*Corresponding author: Xiujin Li, $\mathrm{PhD}$, Professor, research interests: biomass waste and bioenergy. 15 Beisanhuan East Road, Chaoyang District, Beijing 100029, China. Tel/Fax: +86-10-64432281, Email: xjlibuct@gmail.com, xjli@mail.buct.edu.cn. the degradation of the crystallinity and hydrolysis of polymers in lignocellulosic compounds and the content of nitrogen in rice straw $^{[5,6]}$. However, the loss in organic matter $(\mathrm{OM})$ and other nutrients during mushroom cultivation resulted that SMS had lower nutritional worth for anaerobic digestion as compared to raw rice straw $^{[7]}$.

Anaerobic digestion (AD) is a process in which organic matter breaks down under natural action of anaerobic microorganisms to produce biomethane while stabilizing strong organic wastes ${ }^{[8]}$. Recent literature showed that the biomethane yield obtained using rice straw as $\mathrm{AD}$ substrate ranged from $135 \mathrm{~L} / \mathrm{kg} \mathrm{VS}$ to $180 \mathrm{~L} / \mathrm{kg}$ VS, suggesting that rice straw has great potential to produce biogas $^{[9-12]}$. At the end of 2010, 273 biogas plants including 47 medium- and large-scale plants using crop straws as the raw material had been built in China ${ }^{[13]}$. However, AD also produces a large amount of final biologically stable and partially hygienic organic byproduct called digestate, which might lead to negative environmental consequences if it is not disposed of well.

Previous studies showed that anaerobic digestate was considered a suitable organic fertilizers for soil conditioning and plant nourishment ${ }^{[14]}$. Evaluation of the fertilizer properties of anaerobic digestate revealed that the properties of anaerobic digestate primarily depends on the nature of the feedstock ${ }^{[15]}$. SMS contains abundant nutrients including organics, nitrogen $(\mathrm{N})$ and phosphorous $(\mathrm{P})$ which could be slowly released and consumed as their respective soluble forms ${ }^{[16]}$. Hence, application of digestate from anaerobic reactors using SMS as raw material could yield similar or higher crop products compared to digestate of raw straw $^{[17]}$.

Although rice straw has great potential to be used as a biomass source to produce different kinds of value-added products. So far, no single method that can achieve the full utilization of rice straw. Nowadays, green agriculture has already become a priority theme for sustainable development in $\mathrm{China}^{[18]}$. Previous researches focused on the fungal pretreatment reported that the degradation of 
lignin and biomethane production potential of the biomass averagely increased by $50 \%{ }^{[19,20]}$. However, the fungi itself consume some amount of accessible carbon from raw material during simultaneous degradation of holocellulose, even though the species were highly selective to delignification, the loss of carbon from other components of lignocellulose was inevitable ${ }^{[21]}$. The carbon removed during this process was converted to either mycelium or carbon dioxide. Moreover, long pretreatment time is another common limitation of applying fungal pretreatment, because fungal degradation often occurs slowly until the optimum amount of lignin removed from the raw material. To cope with those limitations, choosing edible mushroom species could be a better option to substitute the function fungi because it could achieve a similar effect on delignification in the same cultivation time while producing high-value mushroom fruit. A few studies combined solid-state anaerobic digestion (SS-AD) and Shiitake cultivation for utilization of wood biomass and approached to a positive effect because fungal pretreatment is particularly efficient on the substrate with high lignin content ${ }^{[22,23]}$. However, as far as our knowledge concerned there is no report on the viability of combining edible mushroom cultivation, biomethane production, and fertilizer use for full utilization of nutrients in rice straw, and give a specific analysis of the conversion of mass, elements, and energy during the whole process. Hence, methods on full utilization and complete cycling of rice straw, which formed a biogas project linked eco agricultural engineering model, should become the focal point for researchers in the future. Consequently, this study proposed a feasible way to combine three independent processes (mushroom cultivation, biogas production, and fertilizer use) to generate multiple products, and introduce material and energy cycling from rice straw. Based on a perspective of full utilization of rice straw, this study aimed not only to provide energy but also to circulate biomass in an integrated rice-mushroom-biogas-fertilizer-rice process.

In this study, an integrated process was set up to present a small circulation system and achieve the full utilization of rice straw. Initially, the edible mushroom, Pleurotus ostreatus $(P$. ostreatus) was cultivated on rice straw as the first kind of value-added product. Then, SMS after mushroom cultivation was used as the substrate for anaerobic digestion to generate biogas as the second kind of product. Finally, after AD, the digestate was prepared for organic fertilizer. The production and properties of the $P$. ostreatus, biogas, and digestate generated from each process were analyzed and evaluated based on their specific parameters. Furthermore, the mass balance by the integrated rice-mushroom-biogas-fertilizer-rice process was investigated to account for the introduction of a complete cycle of the agricultural ecosystem.

\section{Materials and methods}

\subsection{Spawn, feedstock, and inoculum}

The spawn of edible mushroom ( $P$. ostreatus) cultivated on sawdust was purchased from Institute of Microbiology, Hei Longjiang Academy of Sciences, Hei Longjiang, China. The purchased spawn was immediately inoculated on the rice straw within $24 \mathrm{~h}$ at room temperature.

Rice straw used in this study was collected from Wuqing District, Tianjin, China. The straw was air-dried until the moisture content was less than $10 \%$ and chopped into $30-40 \mathrm{~mm}$ in length, and then ground into the size of 20-mesh by a hammer mill (YSW-180, Yanshan Zhengde Co, Beijing, China). Then the prepared straw was sub packaged in ziplock plastic bags at room temperature until used for the next test.

The inoculum was collected from continuously operated stable biogas plant for swine manure treatment in Shunyi District, Beijing, China. The main characteristics of rice straw and inoculum were listed in Table 1.

Table 1 Characteristics of rice straw and inoculum*

\begin{tabular}{|c|c|c|}
\hline Items & Rice straw & Inoculum \\
\hline $\mathrm{TS}^{\mathrm{a}} / \%$ & $94.8 \pm 0.3$ & $13.3 \pm 0.0$ \\
\hline $\mathrm{VS}^{\mathrm{a}} / \%$ & $85.9 \pm 0.1$ & $7.3 \pm 0.1$ \\
\hline $\operatorname{MLSS}^{\mathrm{a}} / \mathrm{g} \cdot \mathrm{L}^{-1}$ & -- & $141.3 \pm 0.0$ \\
\hline $\mathrm{TC}^{\mathrm{b}} / \%$ & $40.4 \pm 0.1$ & $29.2 \pm 0.7$ \\
\hline $\mathrm{TN}^{\mathrm{b}} / \%$ & $0.7 \pm 0.0$ & $2.8 \pm 0.0$ \\
\hline $\mathrm{TP}^{\mathrm{b}} / \mathrm{mg} \cdot(\mathrm{kg} \mathrm{TS})^{-1}$ & $8740.5 \pm 180.8$ & $34370.8 \pm 703.6$ \\
\hline $\mathrm{TK}^{\mathrm{b}} / \mathrm{mg} \cdot(\mathrm{kg} \mathrm{TS})^{-1}$ & $1076.8 \pm 70.5$ & $14228.6 \pm 369.6$ \\
\hline $\mathrm{C} / \mathrm{N}^{\mathrm{b}}$ & 56.2 & 10.5 \\
\hline Cellulose $/ \%$ & $34.4 \pm 0.2$ & -- \\
\hline Hemicellulose $\mathrm{e}^{\mathrm{b}} / \%$ & $22.5 \pm 0.8$ & -- \\
\hline $\operatorname{Lignin}^{\mathrm{b}} / \%$ & $5.4 \pm 0.3$ & -- \\
\hline
\end{tabular}

\subsection{Experimental set-up}

\subsubsection{P. ostreatus cultivation}

Rice straw was used to cultivate $P$. ostreatus as a mono-substrate. Deionized water was added until the moisture content of the rice straw reach $65 \%$, which was believed to be the optimum moisture content for the growth of P.ostreatus. The initial $\mathrm{pH}$ of moisturized rice straw (6.1) was adjusted to 7.5-8.0 using lime. Then the substrate was mixed as evenly as possible and soaked overnight following a recipe for P.ostreatus production $^{[24]}$. Mixed substrate $(1 \mathrm{~kg})$ was loaded into each polypropylene bag $(17 \mathrm{~cm} \times 33 \mathrm{~cm} \times 5 \mathrm{~cm})$ with an additional plug and plastic ring; then compacted manually and autoclaved at $121^{\circ} \mathrm{C}$ for $2 \mathrm{~h}$. The prepared substrates were cooled to room temperature before inoculation.

$60 \mathrm{~g}$ of the spawn (3\%-8\% of the weight of the substrate) was added to each bag which contains the thoroughly mixed rice straw substrate. These ready bags were incubated at $25^{\circ} \mathrm{C}-28^{\circ} \mathrm{C}$ and $40 \%-50 \%$ humidity. After 30 days of spawn run time, the mushroom primordia formed and initiated reproductive growth of the species. When the fruiting bodies were formed, the bags were opened and transferred to a shelf in a sterilized room at $30^{\circ} \mathrm{C}$ and over $90 \%$ humidity. The mushrooms were only harvested for one flush after $10 \mathrm{~d}$.

\subsubsection{Anaerobic digestion}

After harvesting the mushroom, the SMS was mixed evenly prior to sampling for characteristic analysis and AD. Anaerobic batch tests were carried out on blue cap bottles with total volume and working volume of $1 \mathrm{~L}$ and $0.8 \mathrm{~L}$, respectively. The organic loading of the substrate and inoculum were set at $50 \mathrm{~g}$ TS/L and $15 \mathrm{~g} \mathrm{MLSS} / \mathrm{L}$, respectively. The initial $\mathrm{pH}$ of each bottle was $7.5 \pm 0.3$. Afterward, the bottles were incubated in a water bath at $35^{\circ} \mathrm{C} \pm 2{ }^{\circ} \mathrm{C}$ with manual shaking for twice a day in a uniform frequency for $45 \mathrm{~d}$ of $\mathrm{AD}$ period. The daily biogas production and methane content were monitored every day to evaluate the biomethane production performances.

\subsubsection{Fertilizer value evaluation}

The fertilizer properties of digestate generated after $\mathrm{AD}$ were analyzed according to the People's Republic of China agricultural industry standards (NY 525-2012) ${ }^{[25]}$. 


\subsection{Analysis methods}

Total solid (TS), volatile solid (VS) and mixed liquid suspended solids (MLSS) were measured according to the APHA standards ${ }^{[26]}$. The $\mathrm{pH}$ was measured with a $\mathrm{pH}$ meter (3-Star, Thermo Orion, America). Ammonia nitrogen $\left(\mathrm{NH}_{4}{ }^{+} \mathrm{N}\right)$ concentration was measured by Kjeldahl analyzer (KT-260, Foss, Danmark). Total carbon (TC), total hydrogen (TH), and total nitrogen $(\mathrm{TN})$ were determined by the elemental analyzer (Vario EL/micro cube elemental analyzer, Germany). Total oxygen (TO) was calculated by the elementary formula $\left(\mathrm{C}_{n} \mathrm{H}_{a} \mathrm{O}_{b} \mathrm{~N}_{e} \mathrm{~S}_{f}\right)$ of the organic matter. Total potassium (TK), total phosphorus (TP), and heavy metals $(\mathrm{Cr}, \mathrm{As}, \mathrm{Cd}, \mathrm{Hg}$ and $\mathrm{Pb}$ ) were determined by the elemental analyzer (IRIS INTREPID II, Thermo Elemental, USA, ICPS-7500, Shimadzu, Japan). Organic matter, available N, P, and $\mathrm{K}$ were measured using the methods described by Ma et al. ${ }^{[27]}$

The characteristics and nutritional value of mushrooms were measured according to the methods adopted from Colavolpe and Albertó $^{[28]}$. Biological efficiency (BE) was used to evaluate the yields, $\%$, and was calculated as follows:

$$
B E=F W / D W \times 100
$$

where, $F W$ is fresh weight, $\mathrm{g}$, of the mushroom yield and $D W$ is the dry weight of the substrate, $\mathrm{g}^{[29]}$. The content of cellulose, hemicellulose, and lignin were measured using fiber analyzer (A2000I, ANKOM, USA).

Biogas production was measured by the water displacement method. Biogas composition $\left(\mathrm{H}_{2}, \mathrm{~N}_{2}, \mathrm{CH}_{4}\right.$, and $\left.\mathrm{CO}_{2}\right)$ was detected by gas chromatography (SP2100, BeiFenRuiLi, Beijing, China) with a TDX-01 column ( $2 \mathrm{~m} \times 3 \mathrm{~mm}$ stainless-steel column $)$ and a thermal conductivity detector (TCD). The operational temperature of injection, column, and detector was $150^{\circ} \mathrm{C}, 140^{\circ} \mathrm{C}$, and $150^{\circ} \mathrm{C}$, respectively. Argon was used as the carrier gas at a flow rate of $30 \mathrm{~mL} / \mathrm{min}$. Daily methane production was calculated after transforming to standard conditions (STP).

The content of total VFAs in digestate was determined using the gas chromatograph (GC2014, Shimadzu, Japan) equipped with a flame ionization detector (FID) and a DB-WAX123-7032 capillary column. Nitrogen was used as the carrier gas. The operational temperatures of injector, detector and column were kept at $250^{\circ} \mathrm{C}$, and increased from $100^{\circ} \mathrm{C}$ to $180^{\circ} \mathrm{C}$ at a rate of $5^{\circ} \mathrm{C} / \mathrm{min}$, respectively.

Each analytical result was reported as the mean value of three replicate sample measurements. The standard deviations and statistical differences were analyzed by Microsoft Excel 2016. All figures in this paper were drawn using OriginPro 9.0 software.

\subsection{Energy assessment}

An energy assessment of the integrated process was set up to evaluate its scalability. To make the assessment, the scale of the process had to be increased. The parameters for the process were estimated from experimental data, using $1 \mathrm{t}$ TS rice straw. The parameters for the mushroom cultivation, $\mathrm{AD}$ and fertilizer use were adapted from previous studies ${ }^{[30-34]}$. More specifically, the energy assessment included input, output and energy balance assessment.

The input energy of mushroom cultivation include heat preservation, electricity and water were calculated based on the energy coefficient from the previous study ${ }^{[30]}$.

The energy inputs for anaerobic digestion were the energy for heating and electricity for mixing. Where its calculations were done according to Equations (2) and (3) in a modified manner as described in the literature ${ }^{[31]}$.

$$
E_{i, h}=86.4 \rho Q \gamma\left(T_{\mathrm{d}}-T_{\mathrm{a}}\right)+k A\left(T_{\mathrm{d}}-T_{\mathrm{a}}\right)
$$

where, $E_{i, h}$ is input heat, $\mathrm{kJ} ; \rho$ is density, $\mathrm{kg} / \mathrm{m}^{3} ; Q$ is biomethane production, $\mathrm{m}^{3} ; \gamma$ is specific heat, $\mathrm{kJ} /\left(\mathrm{kg}^{-1} \cdot{ }^{\circ} \mathrm{C}\right) ; T_{\mathrm{d}}$ is anaerobic digestion temperature, $35^{\circ} \mathrm{C} ; T_{\mathrm{a}}$ is ambient temperature, $25^{\circ} \mathrm{C} ; k$ is heat transfer coefficient, $\mathrm{W} /\left(\mathrm{m}^{2} \cdot{ }^{\circ} \mathrm{C}\right) ; A$ is surface area of the reactor wall, $\mathrm{m}^{2}$.

$$
E_{i, e}=V \omega
$$

where, $E_{i, e}$ is input electricity, $\mathrm{MJ} ; V$ is useful volume, $\mathrm{m}^{3} ; \omega$ is electricity consumption for mixing, $\mathrm{MJ} / \mathrm{m}^{3}$.

Normally, the digestate had to be dewatered to make the content of TS up to $30 \%$ before its fertilizer use ${ }^{[35]}$. Its energy input (Equation (4)) was calculated using the modified equation ${ }^{[32]}$.

$$
E_{i, d}=3600 Q_{\mathrm{d}} k_{\mathrm{d}}
$$

where, $E_{i, d}$ is the energy input of digestate dewatering, MJ; $Q_{\mathrm{d}}$ is the quantity of total dry solid for digestate, $\mathrm{kg} ; k_{\mathrm{d}}$ is the specific energy consumption, $35 \times 10^{-3} \mathrm{kWh} / \mathrm{kg}$.

The energy output from the mushroom cultivation, anaerobic digestion, and fertilizer use were calculated from the mushroom yield, methane yield, and the estimated crops yield after the land application of the dewatered digestate.

Finally, energy assessment was expressed as net energy output $(\Delta \mathrm{E})$, energy ratio $(R)$, and energy conversion efficiency of the degraded substrate $(\eta)$ was calculated based on Equations $(5)-(7)^{[33]}$ :

$$
\begin{gathered}
\Delta E=E_{\mathrm{o}}-E_{\mathrm{i}} \\
R=E_{\mathrm{o}} / E_{\mathrm{i}} \\
\eta=\Delta E / O L R V R_{\mathrm{s}}
\end{gathered}
$$

where, $\Delta E$ is the net energy output, $\mathrm{MJ} ; E_{\mathrm{o}}$ is the energy output, MJ; $E_{i}$ is the energy input, $\mathrm{MJ} ; R$ is the energy ratio; $\eta$ is the energy conversion efficiency of degraded organic matter, $\mathrm{MJ} / \mathrm{kg}$ Degraded VS; OLR is organic loading rate, $\mathrm{kg} \mathrm{VS} / \mathrm{m}^{3} ; V$ is useful volume, $\mathrm{m}^{3}$; $R_{\mathrm{S}}$ is the degradation rate of organic matter, $\%$.

\section{Results and discussion}

\subsection{P. ostreatus cultivation}

The morphological structures of fruiting bodies on rice straw at different growth stages were shown in Figure 1. It took $30 \mathrm{~d}$ to grow mycelium on the rice straw. The matured fruiting bodies were formed $10 \mathrm{~d}$ later after the formation of the primordium. The pileus of the fruiting bodies harvested from all bags were white in color. The average pileus diameter, stipes length, and stipe diameter of fruiting bodies on rice straw was $6.3 \mathrm{~cm}, 3.9 \mathrm{~cm}$, and $0.6 \mathrm{~cm}$, respectively (Table 2). The morphological structures of fruiting bodies harvested from different rice straw bags were as almost similar to that of oyster mushroom cultivar on rice and wheat straw ${ }^{[36]}$.

In this study, the fruiting bodies were harvested just once so that the majority of the remaining organic matter (SMS) reserved for the AD process. The average weight of the fruiting body yield and BE of one flush was $133.1 \mathrm{~g}$ and $40.1 \%$, respectively (Table 2), which was in line with the results reported by Vieira ${ }^{[37]}$.

Nutritional value of the dried fruiting bodies cultivated on rice straw was tested. Based on the results, the moisture and ash contents were $88.8 \%$ and $4.2 \%$, respectively (Table 2 ), indicating that the fruiting bodies harvested from rice straw were fresh and had high moisture content ${ }^{[38]}$. Crude polysaccharides and crude protein were the main compositions of mushroom, the cultivated $P$. ostreatus were proved to have a relatively high content of those among other mushroom species ${ }^{[39]}$. The results showed that the crude polysaccharides, protein, fiber and fat content of fruiting bodies were $34.9 \%, 18.7 \%, 8.1 \%$, and $5.4 \%$, respectively (Table 2 ), which were comparable to previous reports ${ }^{[38]}$. 


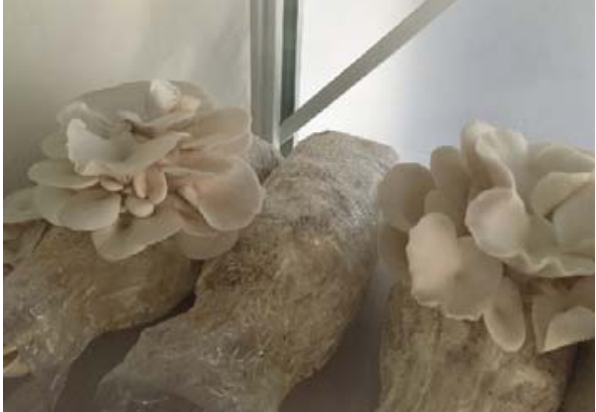

a. P. ostreatus cultivation on rice straw

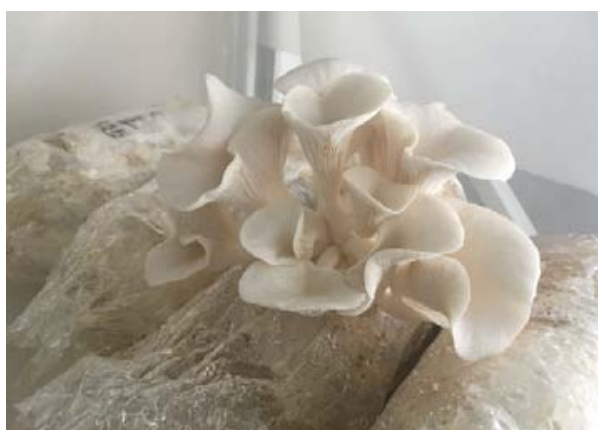

b. Mature mushroom fruiting body

Figure 1 Mature mushroom fruiting body of $P$. ostreatus on rice straw

Table 2 Morphological structure and nutritional values of P. ostreatus mushrooms*

\begin{tabular}{|c|c|c|}
\hline & Items & Values \\
\hline \multirow{5}{*}{$\begin{array}{l}\text { Morphological } \\
\text { structure }\end{array}$} & Fruit bodies yield/g & $133.1 \pm 4.6$ \\
\hline & Biological efficiency $/ \%$ & $40.1 \pm 1.4$ \\
\hline & Pileus diameter/cm & $6.3 \pm 0.8$ \\
\hline & Stipe length/cm & $3.9 \pm 0.6$ \\
\hline & Stipe diameter $/ \mathrm{cm}$ & $0.6 \pm 0.0$ \\
\hline \multirow{6}{*}{$\begin{array}{l}\text { Nutritional } \\
\text { value }\end{array}$} & Moisture $/ \%$ & $88.8 \pm 0.0$ \\
\hline & $\operatorname{Ash}^{\mathrm{a}} / \%$ & $4.2 \pm 0.0$ \\
\hline & Crude polysaccharides $\mathrm{b} / \%$ & $34.9 \pm 0.6$ \\
\hline & Crude protein $\mathrm{b} / \%$ & $18.7 \pm 0.3$ \\
\hline & Crude fiber $/ \%$ & $8.1 \pm 0.5$ \\
\hline & Crude fat ${ }^{\mathrm{b}} / \%$ & $5.4 \pm 0.2$ \\
\hline
\end{tabular}

Note: ${ }^{*}$ Values are means \pm SD $(n=3) ;{ }^{a}$ Content of fresh matter; ${ }^{\mathrm{b}}$ Content of dry matter.

\subsection{Anaerobic digestion}

Daily biogas production (DBP) of SMS is shown in Figure 2a. The experiment showed two peaks of DBP which were gradually approached to zero during the last days of digestion time. More specifically, for SMS, the first peak appeared on day 6 with the DBP of $400 \mathrm{~mL} / \mathrm{d}$ whereas the second DBP peaks reached $650 \mathrm{~mL} / \mathrm{d}$ on day 20. The process performed successfully without any inhibition from VFAs during the digestion time. Reports showed that biogas production in solid-state anaerobic digestion using SMS as raw material was relatively low at the initial phase, which was due to the effect of acidification ${ }^{[40,41]}$. However, in this study, the moisture content of the AD system was $90 \%$, which made SMS more feasible to use as a sole feedstock because the VFAs could be diluted in a liquid system. Compared to solid-state anaerobic digestion, using SMS as feedstock in liquid-state anaerobic digestion shortened the digestion time and increased the biogas production due to avoiding of acidification, which could be worth enough to consider the technological process for the industrial level.
The methane content (MC) of SMS is shown in Figure 2a. During AD of SMS, the MC increased steadily, achieved its $50 \%$ of production at day 14 , and then remained at the level that average methane contents ranged between $50 \%$ and $60 \%$ throughout the digestion time. Reports in the literature showed that methane content in the biogas from rice straw slowly increased and fluctuated at the beginning of digestion time due to acidification of the reactors ${ }^{[42,43]}$. This shows that using SMS as AD feedstock can make methanogenesis predominant at the initial stage of $\mathrm{AD}$, which could be due to the decomposition of the lignin-carbohydrate complex during mushroom cultivation which made the SMS substrate more readily degradable than rice straw. So that, SMS was more utilized by anaerobic microorganism during $\mathrm{AD}$ than rice straw.

Cumulative biogas production (CBP) and cumulative biomethane production (CMP) showed in Figure $2 \mathrm{~b}$ was $9840 \mathrm{~mL}$ and $4812 \mathrm{~mL}$ for SMS, respectively. CBP and CMP of SMS showed a similar trend, which was gradually increased in the first 20 days and approached a constant value during the last days of digestion time. Additionally, this result was consistent with the trend of DBP and MC of the anaerobic digestion process in this study. The VS biomethane yield was $133.0 \mathrm{~mL} / \mathrm{g}$ VS. Feng et al. ${ }^{[44]}$ reported that the methane production potential of $P$. eryngii spent compost material was $194 \mathrm{~L} / \mathrm{kg} \mathrm{VS}$; P. ostreatus pretreated rice straw was $167 \mathrm{~L} / \mathrm{kg} \mathrm{VS}^{[19]}$. This indicates that SMS still has great potential for methane conversion, and is a considerable substrate for biogas production.

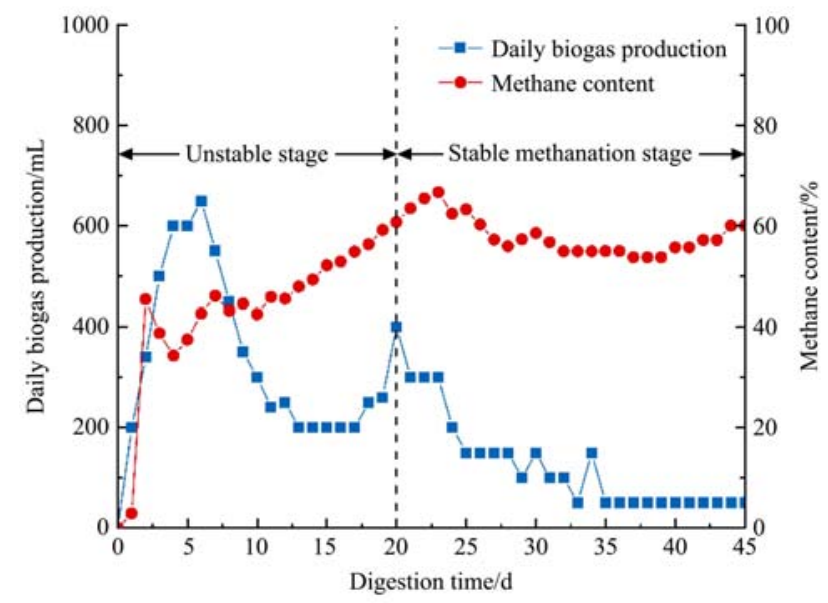

a. Daily biogas production and methane content

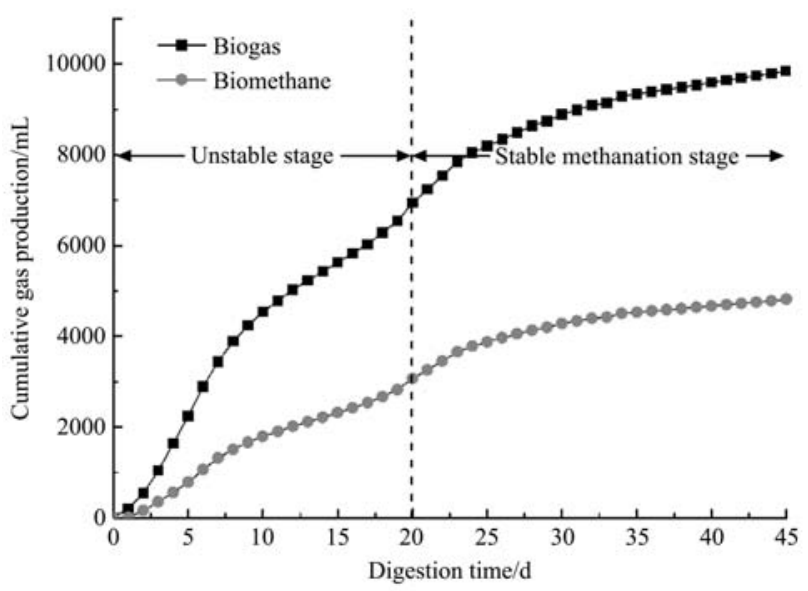

b. Cumulative biogas and biomethane production

Figure 2 Daily biogas production, methane content, and cumulative biogas and biomethane production during AD of SMS 
The time required to produce $80 \%$ of the maximal biomethane production $\left(T_{80}\right)$ is used to evaluate the digestion performance of AD processes ${ }^{[45]}$. The $T_{80}$ for SMS was $25 \pm 1$ days and the shorter digestion time $(10.7 \%$ shorter than that of the control test in previous studies) ${ }^{[46]}$ could be associated to delignification of the substrate by mushroom cultivation.

\subsection{Fertilizer value evaluation}

Anaerobic digestate contains a high proportion of nutritional components such as nitrogen $(\mathrm{N})$, phosphorus $(\mathrm{P})$, and potassium $(\mathrm{K})$, which were necessary nutrients source for crops. Some parameters of the digestate after anaerobic digestion of SMS to evaluate the fertilizer properties are shown in Table 3. Data showed in this section was the contents based on dry matter. $\mathrm{N}$ is an important nutrient and is the most common plant growth necessary factor of crops. Previous test showed that $\mathrm{NH}_{4}^{+}$in digestate would convert to $\mathrm{NO}_{3}{ }^{-}$and used by crops. Moreover, the net organic $\mathrm{N}$ and $\mathrm{P}$ in digestate also be partly used for crops growth $^{[47]}$. In the integrated process, mushroom cultivation on rice straw has an advantage in decreasing the $\mathrm{C} / \mathrm{N}$ ratio to the optimum level for $\mathrm{AD}$ of SMS, meanwhile, increasing the $\mathrm{TN}$ content of digestate. Transformation of TN from SMS to digestate was $99.75 \%$, suggesting most of the $\mathrm{N}$ was preserved. During $\mathrm{AD}$, complex organic $\mathrm{N}$ compounds were mineralized and formed as available $\mathrm{N}$, such as $\mathrm{NH}_{4}{ }^{+}-\mathrm{N}(417.7 \mathrm{mg} / \mathrm{L})$ and allowed its immediate utilization by crops. The presence of $\mathrm{NH}_{4}^{+}$could also lead to the formation of $\left(\mathrm{NH}_{4}\right)_{2} \mathrm{CO}_{3}$ and increase the $\mathrm{pH}$ of digestate. It is a useful property to solve the problem of soil acidification.

Table 3 Fertilizer properties of digestate ${ }^{*}$

\begin{tabular}{lcc}
\hline \multicolumn{1}{c}{ Items } & Content & $\begin{array}{c}\text { Organic fertilizer } \\
(\mathrm{NY} 525-2012)^{\mathrm{c}}\end{array}$ \\
\hline Organic matter $/ \%$ & $59.5 \pm 1.3$ & $\geq 45.0$ \\
$\mathrm{Total} \mathrm{N}^{\mathrm{a}} \mathrm{g} / \mathrm{kg} \mathrm{TS}$ & $16.4 \pm 2.1$ & - \\
$\mathrm{P}_{2} \mathrm{O}_{5}{ }^{\mathrm{a}} \mathrm{g} / \mathrm{kg} \mathrm{TS}$ & $24.0 \pm 1.1$ & - \\
$\mathrm{K}_{2} \mathrm{O}^{\mathrm{a}} \mathrm{g} / \mathrm{kg} \mathrm{TS}$ & $15.0 \pm 1.5$ & - \\
Nutrients $\left(\right.$ Total N $\left.+\mathrm{P}_{2} \mathrm{O}_{5}+\mathrm{K}_{2} \mathrm{O}\right) / \%$ & 5.5 & $\geq 5.0$ \\
$\mathrm{Moisture}^{\mathrm{b}} / \%$ & $95.7 \pm 2.1$ & $\leq 30.0$ \\
$\mathrm{pH}^{\mathrm{b}}$ & $7.2 \pm 0.0$ & $5.5-8.5$ \\
\hline Note: ${ }^{*}$ Values are means $\pm \mathrm{SD}(n=3) ;{ }^{\mathrm{a}}$ Content of dry matter; ${ }^{\mathrm{b}}$ Content of fresh \\
matter; ${ }^{\mathrm{c}}$ People's Republic of China agricultural industry standards.
\end{tabular}

Phosphorous was another important plant nutrient in digestate. The amount of $\mathrm{P}$ in the form of $\mathrm{P}_{2} \mathrm{O}_{5}$ in digestate was $10.5 \mathrm{~g} / \mathrm{kg} \mathrm{TS}$. A study showed that fungal could transform $\mathrm{P}$ from the organic state into a soluble form ${ }^{[29]}$, indicating that $\mathrm{P}$ in SMS will be easily used by microorganism during AD. Anaerobic microorganisms also enhanced hydrolyzable of $\mathrm{P}$ containing substrates during degradation processes of $\mathrm{AD}$ and transferred it into a liquid fraction, which was consistent with the result of the available $\mathrm{P}$ content in this study.

The content of $\mathrm{K}\left(\mathrm{K}_{2} \mathrm{O}\right)$ in digestate was $12.5 \mathrm{~g} / \mathrm{kg}$ TS. The high content of $\mathrm{K}$ in digestate has a positive aspect because it could be used as a nutritional supplement to improve the property of the digestate as fertilizer. The amount of $\mathrm{K}$ remained after $\mathrm{AD}$ of the SMS was $92.6 \%$, indicating that almost all the $\mathrm{K}$ in the SMS remained in digestate. This result assures that the digestate of SMS could highly increase the content $\mathrm{K}$ in the soil when used as organic fertilizer.

Available $\mathrm{N}$ includes ammonium nitrogen, nitrate nitrogen, amino nitrogen, amide nitrogen and $\mathrm{N}$ from some simple peptide and protein compounds, which are soluble and easy to be absorbed by the plant ${ }^{[48]}$. Available $\mathrm{P}$ and $\mathrm{K}$ are the $\mathrm{P}$ and $\mathrm{K}$ components that can be absorbed by plants, including all water-soluble $\mathrm{P}, \mathrm{K}$ partially adsorbed phosphorus and organic P. In this study, available $\mathrm{N}, \mathrm{P}$, and $\mathrm{K}$ in liquid fractions of digestate were also analyzed to evaluate the fertilizer property of digestate obtained from integrated processes (Table 4). The results showed that the available nutrients content of the digestate is $3.3 \%$ of its total nutrients content. Moreover, the ratio of available $\mathrm{P} /$ available $\mathrm{K}$ was approximately $1: 3$, which was good for the growth of grains ${ }^{[49]}$ Based on this result, the integrated process could be a practical method to improve the nutrient's availability during $\mathrm{AD}$ and promote the quick-release of those elements as nutrients supplement for soil.

In the organic fertilizer used in China, the total contents of $\mathrm{N}$, $\mathrm{P}_{2} \mathrm{O}_{5}$, and $\mathrm{K}_{2} \mathrm{O}$ compounds should be greater than or equal to $5 \%$ based on dry weight ${ }^{[25]}$. Hence, digestate of SMS was acceptable and achieved the complete circulation of nutrients via the rice-mushroom-biogas-fertilizer-rice process.

In the $\mathrm{AD}$ process, heavy metals might arise from input feedstock and remain in the digestate ${ }^{[50]}$. The content of five kinds of heavy metals in digestate of SMS was also analyzed in this study (Table 4). Cr was found as the most prevalent heavy metal in the digestate, followed by $\mathrm{Pb}$ and As, however, there were no traces of $\mathrm{Cd}$ or $\mathrm{Hg}$ detected. National regulations in China prohibit the use of digestate if the concentration of one or more heavy metal exceeds a certain limit. As People's Republic of China agricultural industry standards, the maximum permissible limit has been set for $\mathrm{Cr}$, As, $\mathrm{Cd}, \mathrm{Hg}$, and $\mathrm{Pb}$, which are 150, 15, 3, 2 , and $50 \mathrm{mg} / \mathrm{kg} \mathrm{TS}$, respectively ${ }^{[25]}$. It was observed that the content of heavy metals in SMS based digestate in this study had no harmful health implications of their applications.

Table 4 Available N, P, and $\mathrm{K}$ in liquid fractions and heavy metals content of digestate ${ }^{*}$

\begin{tabular}{cc}
\hline \multicolumn{1}{c}{ Items } & Content \\
\hline Available $\mathrm{N}^{\mathrm{a}} / \mathrm{mg} \cdot(\mathrm{kg} \mathrm{TS})^{-1}$ & $0.4 \pm 0.0$ \\
Available $\mathrm{P}^{\mathrm{a}} / \mathrm{mg} \cdot(\mathrm{kg} \mathrm{TS})^{-1}$ & $0.2 \pm 0.0$ \\
Available $\mathrm{K}^{\mathrm{a}} / \mathrm{g} \cdot(\mathrm{kg} \mathrm{TS})^{-1}$ & $0.7 \pm 0.0$ \\
$\mathrm{Cr}^{\mathrm{a}} / \mathrm{mg} \cdot(\mathrm{kg} \mathrm{TS})^{-1}$ & $11.2 \pm 0.2$ \\
$\mathrm{As}^{\mathrm{a}} / \mathrm{mg} \cdot(\mathrm{kg} \mathrm{TS})^{-1}$ & $4.4 \pm 0.1$ \\
$\mathrm{Cd}^{\mathrm{a}} / \mathrm{mg} \cdot(\mathrm{kg} \mathrm{TS})^{-1}$ & $\mathrm{ND}^{\mathrm{b}}$ \\
$\mathrm{Hg}^{\mathrm{a}} / \mathrm{mg}^{\mathrm{b}}(\mathrm{kg} \mathrm{TS})^{-1}$ & $\mathrm{ND}^{\mathrm{b}}$ \\
$\mathrm{Pb}^{\mathrm{a}} / \mathrm{mg} \cdot(\mathrm{kg} \mathrm{TS})^{-1}$ & $6.2 \pm 0.1$ \\
\hline
\end{tabular}

Note: * Values are means $\pm \mathrm{SD}(n=3) ;{ }^{\mathrm{a}}$ Content of fresh matter; ${ }^{\mathrm{b}}$ ND represents non-detected.

\subsection{Mass balance}

Conversion of compositions in rice straw was used to assess the $\mathrm{AD}$ performance and calculate the utilization rate of rice straw after three processes.

\subsubsection{Conversion of TS and VS}

TS and VS conversion of rice straw in the integrated processes are given in Figure 3a. The calculation was based on that the initial TS value of rice straw was $1000 \mathrm{~g}$. The conversion of TS of rice straw to mushroom, biogas, and digestate was $4.5 \%, 41.8 \%$, and $44.9 \%$, respectively. On the hand, the degradation of TS and VS of rice straw after cultivation of mushroom was $13.30 \%$ and $16.43 \%$, respectively. This was due to the decomposition of rice straw components by $P$. ostreatus as nutrients for the growth of mycelium to develop fruiting bodies. Moreover, the combination of mushroom cultivation and $\mathrm{AD}$ increased the removal of the total TS and VS reduction to $55.1 \%$ and $60.8 \%$, respectively (Figure $3 \mathrm{a}$ ). 
More specifically, the total TS and VS reduction during the integrated process was increased by $35.6 \%$ and $47.0 \%$ compared to only $\mathrm{AD}$, This TS and VS reduction rate was $1.3 \%$ and $24.0 \%$, respectively higher than the findings from Dai et al. ${ }^{[51]}$ which used $\mathrm{AD}$ of $6 \% \mathrm{NaOH}$ pretreated rice straw. In another sense, the integrated process improved the total solid reduction of the process and converted to mushroom and biogas.

\subsubsection{Conversion of organic matter}

Conversion of organic matter $(\mathrm{OM})$ in rice straw (major components are carbohydrates, lignocellulose N-containing compounds, fat, resin, wax, and tannin $)^{[52,53]}$ during three experimental processes is given in Figure 3a. In the first stage of mushroom cultivation, $4.9 \%$ and $72.2 \%$ of the organic matter from rice straw converted to mushroom and SMS, respectively. The loss of the organic matter was mainly due to the metabolism during mushroom growth. The digestate was characterized by relatively low dry matter content and $42.2 \%$ (deducted inoculum) of the organic matter was remained because of the methane conversion (30.0\%) during the $\mathrm{AD}$ stage. Organic matter in digestate contains $81.0 \mathrm{mg} / \mathrm{L}$ of total volatile fatty acid which could be decomposed within a few days and could increase the soil organic matter content. Hence, it was suitable for using the digestate as fertilizer and for soil amendment.

\subsubsection{Conversion of lignocellulose}

The degradation of cellulose, hemicellulose, and lignin of $P$. ostreatus cultivation in the first step of mushroom cultivation were $14.2 \%, 40.9 \%$, and $24.1 \%$, respectively (Figure 3b). The degradation rate of hemicellulose and lignin was significantly higher than that of cellulose $(p<0.05)$. P. ostreatus was proved to have high relative selectivity on lignin degradation of softwood substrates due to the presence of enzymes like laccase, Mn-peroxidase, and Lignin peroxidase ${ }^{[54,55]}$. The results of this study showed that edible mushroom (P.ostreatus) also had significant selectivity on lignin degradation, which made the SMS highly digestible compared to the rice straw. The degradation of hemicellulose was highest among the three compositions, showing that during the cultivation period hemicellulose was the main carbon source for mycelium growth and metabolism. The loss of cellulose in this test $(14.2 \%)$ was relatively lower than that in the report $(32.0 \%)$ by Taniguchi et al. ${ }^{[56]}$

The presence of high cellulose and hemicellulose content in rice straw made the_raw material rich in main carbon sources for anaerobic microbes during the production of methane in the $\mathrm{AD}$ process $^{[57]}$. Lignin is poorly degradable, and holocellulose (cellulose and hemicellulose) is hardly accessible by anaerobic microbes owing to interactions and linkages with lignin networks $^{[58]}$. During AD of SMS, the maximum degradation of cellulose and hemicellulose were $67.1 \%$ and $75.2 \%$, respectively. These results showed that cellulose and hemicellulose in SMS were easily biodegradable, which had a great advantage for methane production from SMS. Although lignin is recalcitrant to $\mathrm{AD}$, however, in this study certain amount of lignin degraded during the AD process. The conversion of lignin from SMS was $4.9 \%$, which could be due to the mushroom cultivation destroyed the structure and the extended digestion time enhanced the breaking of the lignin network ${ }^{[59]}$.

The total conversion rate of cellulose, hemicellulose, and lignin by the combined process of mushroom cultivation on rice straw and followed by AD of SMS was $71.8 \%, 85.3 \%$, and $27.8 \%$, respectively. The cellulose/lignin ratio of digestate has been suggested to be an indicator of the degree of humification of the organic matter. The value of the cellulose/lignin (0.5) represent to the threshold that distinguishes between the fresh and mature substrate, and when the value is higher than 0.5 represent the substrate is fresh ${ }^{[60]}$. In this study the ratio was 2.3 , indicating the digestate was the fresh substrate. It represented that the digestate could be used as organic fertilizer after compost, and the integrated process could improve the utilization rate of lignocellulose in rice straw.
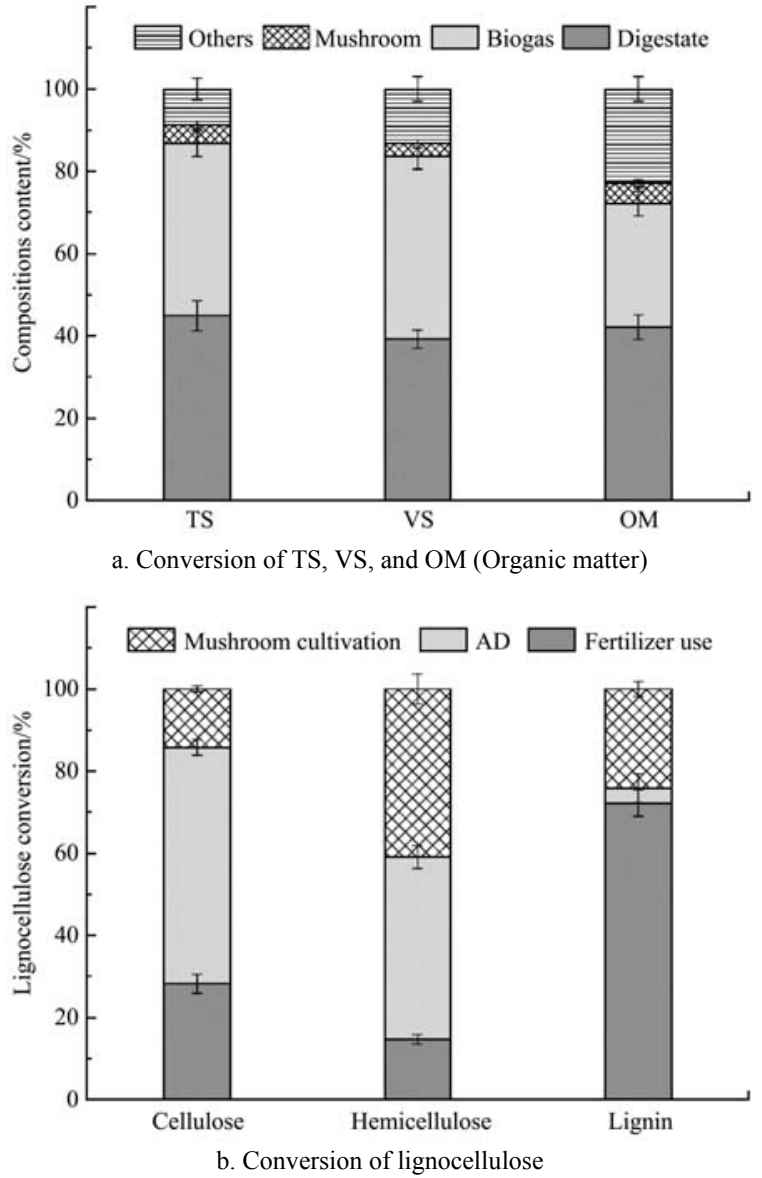

Figure 3 Conversion of TS, VS, and organic matter (OM), and lignocellulose during the integrated processes

\subsubsection{Transformation of carbon, hydrogen, and oxygen}

Transformation of carbon, hydrogen, and oxygen from rice straw to multiple products during the integrated process was the key parameter to evaluate the efficiency of mass utilization and bioenergy conversion (Figure 4). The amount of carbon, hydrogen, and oxygen in biogas were calculated by assuming that those elements containing compounds in biogas were carbon dioxide and methane gas. In this study, $8.1 \%, 8.1 \%, 5.7 \%$; and $39.0 \%, 44.9 \%, 34.0 \%$ of the carbon, hydrogen, and oxygen were used to form mushroom and biogas, which brought economic efficiency and energy valorization by elements utilization form update. Moreover, $52.9 \%, 47.0 \%$, and $60.3 \%$ of carbon, hydrogen, and oxygen were remained in digestate, respectively. As carbon, hydrogen, and oxygen were the main constituent elements of organic matter, this result was consistent with the trend of organic matter conversion.

The amount of carbon in three phases of experimental lines was calculated from biogas, liquid fraction of digestate (LFD), and solid fraction of digestate (SFD) (carbon from inoculum was deducted). The distribution of carbon in gas, liquid, and solids of the $\mathrm{AD}$ process was not shown in this paper. The transformation of carbon into gas depends on the amount of methane and carbon 
dioxide produced during the conversion process which was an important parameter to evaluate the $\mathrm{AD}$ performance ${ }^{[61]}$. The results revealed that the total amount of carbon transformed into gas was $37.0 \%$. The amount of carbon remained in solid was $44.68 \%$, indicating that the SFD obtained from all processes could supplement carbon for the amendment of low carbon agricultural soils. Totally, the remaining $18.4 \%$ of carbon was transferred to LFD; this could be due to the mushroom cultivation which improved the conversion of organic matter in SMS from insoluble organics to soluble substrates like VFAs, and low carbon molecules during $\mathrm{AD}$ process ${ }^{[62]}$.

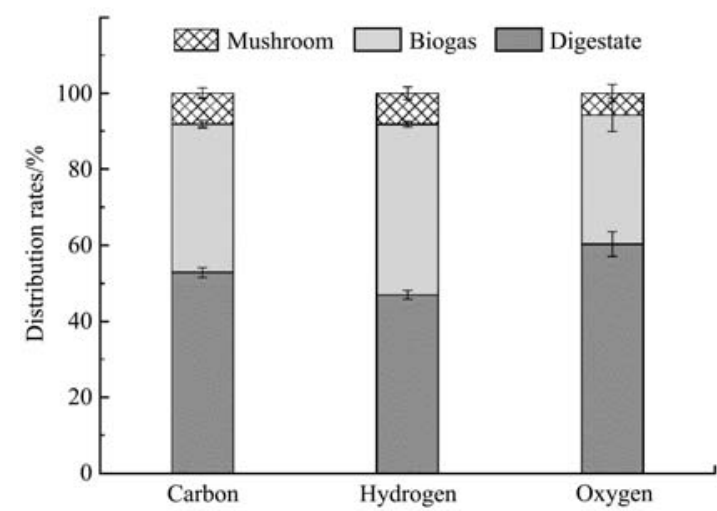

Figure 4 Distribution rates of carbon, hydrogen, and oxygen in mushroom, biogas, and digestate

\subsection{Energy assessment}

In this study, the energy assessment of the integrated process of mushroom cultivation, anaerobic digestion, and fertilizer use were carried out to evaluate its viability. To make the assessment, two traditional approaches and the integrated process such as: process 1 (mushroom cultivation then SMS composting), process 2 (AD then the use of digestate as fertilizer) and process 3 (mushroom cultivation combines $\mathrm{AD}$ and fertilizer use of digestate), respectively (Figure 5) applied and the results are summarized in Table 5 .

Usually, mushroom cultivation combines with the composting process for the subsequent treatment of the SMS. The input energy of mushroom cultivation and SMS composting was $16772 \mathrm{MJ}$ and $315 \mathrm{MJ}$, respectively. The output energy of process 1 was from the calories of edible mushroom and crops. Since mushroom and crops were both low-calorie foods, as a result, the net energy output (NEO) of process 1 was negative. Additionally, in the scale-up process, a large amount of diesel fuel was often consumed for the heating and humidity purpose by substituting electricity, which was the main reason for the negative net energy. Literature result also made the same conclusion that in mushroom production, which stated that the change in energy was negative ${ }^{[30]}$.

Anaerobic digestion is a renewable energy generation process and often followed with the digestate treatment system for organic fertilizer production. As the results summarized in Table 5, the input energy of $\mathrm{AD}$ and fertilizer use was $17980 \mathrm{MJ}$ and $93 \mathrm{MJ}$, respectively. The high energy input for $\mathrm{AD}$ are attributed to the energy applied for reactor heating and biomass mixing. On the other hand, dewatering is also the main energy consuming process for digestate treatment to increase its solids content. Total energy input of process 2 is higher than that of process 1 . However, the total energy generation of process $2(22800 \mathrm{MJ})$ was much higher than that of process 1 due to the high energy value of biomethane. NEO of process 2 was $4727 \mathrm{MJ}$, and the positive value indicates net energy gain in this stage.

In this study, process 3 which is designed as an integrated process was set up to combine processes 1 and 2. Results showed that the NEO of this process was $1150 \mathrm{MJ}$, indicating that the energy generation from the $\mathrm{AD}$ process can meet the energy consumption of the integrated process, especially the energy deficit during the mushroom cultivation. The energy balance analysis (Table 5) showed the $\Delta E, R$, and $\eta$ of process 3 are higher than those of process 1 while those of process 2 is highest. The results suggest the integrated process can recover energy from the rice straw after mushroom and biogas production, and land application of organic fertilizer. Although when compared to process 2 the net energy production and energy conversion efficiency of process 3 decreased, the high economic value of mushroom could be an offset.

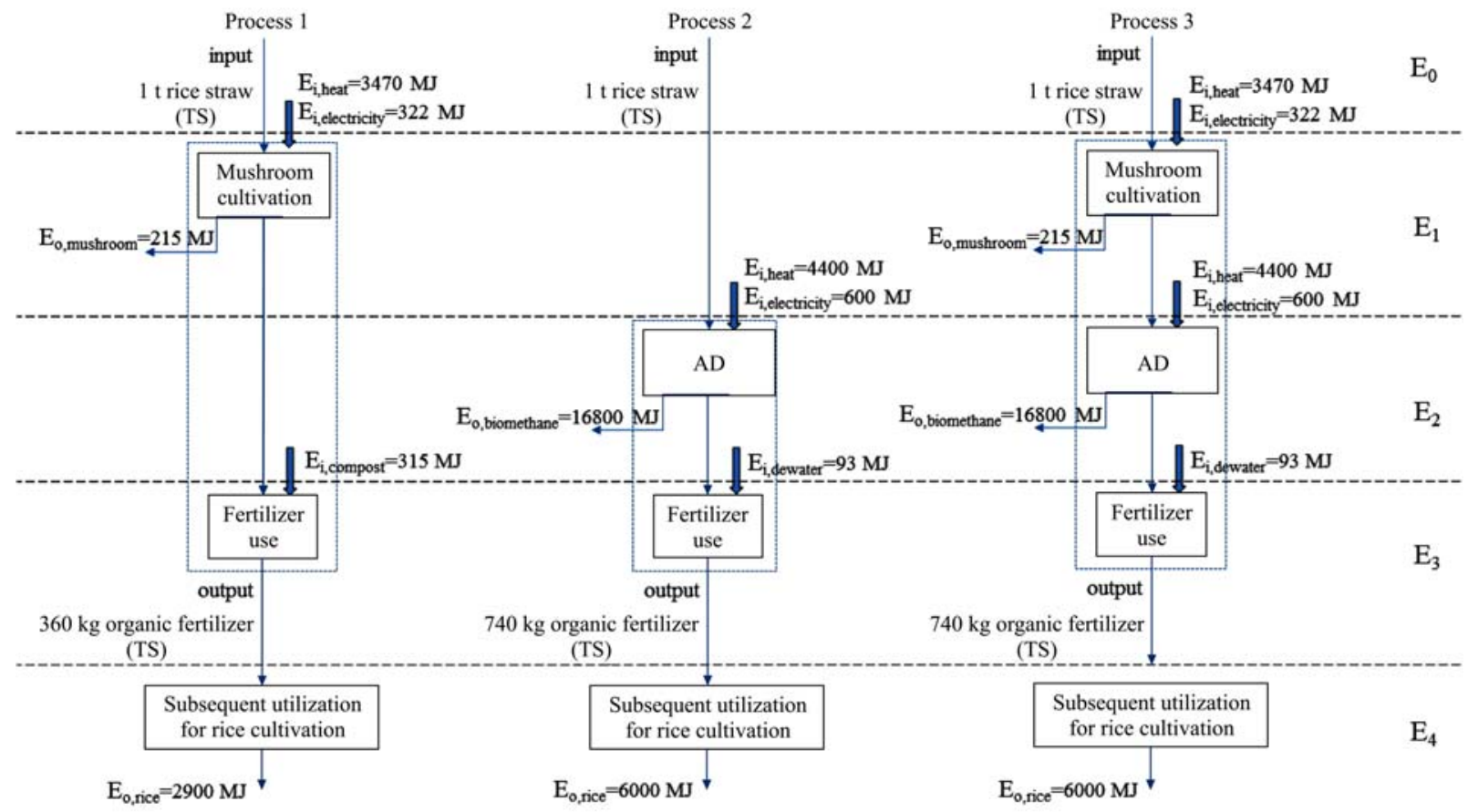

Figure 5 Energy assessment of three processes after scale-up 
Table 5 Energy assessment of three processes after scale-up

\begin{tabular}{|c|c|c|c|c|}
\hline & Item/MJ & Process 1 & Process 2 & Process 3 \\
\hline \multicolumn{5}{|l|}{ Input } \\
\hline Feedstock & $\mathrm{E}_{0}$ & & & \\
\hline Rice straw & $\mathrm{Q}_{\text {rice straw }}^{\mathrm{a}}$ & 12980 & 12980 & 12980 \\
\hline Mushroom cultivation & $\mathrm{E}_{1}$ & & & \\
\hline Heat preservation & $\mathrm{E}_{\mathrm{i}, \text { heat }}$ & 3470 & - & 3470 \\
\hline Electricity & $\mathrm{E}_{\mathrm{i}, \text { electricity }}$ & 320 & - & 320 \\
\hline Water & $\mathrm{E}_{\mathrm{i}, \text { electricity }}$ & 2 & - & 2 \\
\hline $\mathrm{AD}$ & $\mathrm{E}_{2}$ & & & \\
\hline Heat preservation & $\mathrm{E}_{\mathrm{i}, \text { heat }}$ & - & 4400 & 4400 \\
\hline Electricity & $\mathrm{E}_{\mathrm{i}, \text { electricity }}$ & - & 600 & 600 \\
\hline Fertilizer use & $\mathrm{E}_{3}$ & & & \\
\hline Dewatering & $\mathrm{E}_{\mathrm{i}, \text { dewater }}$ & - & 93 & 93 \\
\hline Composting & $\mathrm{E}_{\mathrm{i}, \mathrm{compost}}$ & 315 & - & - \\
\hline Total energy consume & $\mathrm{E}_{\mathrm{i}, \text { total }}$ & 17087 & 18073 & 21865 \\
\hline \multicolumn{5}{|l|}{ Output } \\
\hline Mushroom & $\mathrm{Q}_{\mathrm{o}, \text { mushroom }}{ }^{\mathrm{a}}$ & 215 & - & 215 \\
\hline Biogas & $\mathrm{Q}_{\mathrm{o}, \text { biogas }}^{\mathrm{a}}$ & - & 16800 & 16800 \\
\hline Crops & $\mathrm{Q}_{\mathrm{o}, \text { crops }}\left(\mathrm{E}_{4}\right)^{\mathrm{a}}$ & 2900 & 6000 & 6000 \\
\hline Total energy generation & $\mathrm{Q}_{\mathrm{o}, \text { total }}^{\mathrm{a}}$ & 3115 & 22800 & 23015 \\
\hline \multicolumn{5}{|l|}{ Energy assessment } \\
\hline NEO & $\Delta \mathrm{E}^{\mathrm{b}}$ & -13972 & 4727 & 1150 \\
\hline Energy ratio & $\mathrm{R}^{\mathrm{b}}$ & 0.2 & 1.3 & 1.1 \\
\hline Energy conversion efficiency & $\eta^{\mathrm{b}}$ & -21.8 & 8.6 & 2.1 \\
\hline
\end{tabular}

On the other hand, the distribution of total input energy in the form of renewable (biomass) and non-renewable energy (diesel fuel and electricity) groups in process 3 was $59.4 \%$ and $40.6 \%$. Based on this study, even though the share of renewable energy was higher than that non-renewable energy in process 3 , it still has the gap of the improvement. For example, the diesel fuel can be replaced with an alternative source of energy such as biomethane generated from the $\mathrm{AD}$ during the process. The water consumption for mushroom growth was a big concern cannot be ignored by the integrated process application. The moisture content of the culture substrate is an important factor to absorb and transport nutrients for the growth of mycelium and fruiting body, and also removing metabolic wastes during the cultivation of edible fungi. Therefore, the addition of sufficient water at all stages of growth and development of edible fungi was necessary. Managing water consumption of mushroom cultivation could be achieved by maintaining the suitable moisture content of culture substrate (60\%-70\% moisture) and surrounding (80\%-90\%) for the mycelium development and fruit body formation stage, respectively. However, some measures can be taken to reduce unnecessary wastage of water. For instance, using polypropylene bag to cultivate mushroom and adding water absorbing resin as water retaining agent could keep the moisture of the substrate and avoid frequent addition of water to the culture substrate. On the other hand, the water saving irrigation technique such as a combination of micro-sprinkler and centralized water injection could be used instead of manual spray to reduce water consumption and keeping the environment humid. Furthermore, when using SMS as the feedstock of $\mathrm{AD}$ it does not need adding much extra water to the reactor because SMS has already $60 \%$ moisture content. For these reasons, the integrated process applied in this study can be considered as a cleaner production process, which has the feasibility to be applied after integrating and optimizing.

Generally, the integrated process has economic benefits that are important indicators to evaluate the efficiency of the process of biomass utilization (mushroom cultivation, methane production, and organic fertilizer) apart from waste treatment during the process. Although the complex process could add the capital and operation costs in large-scale, which may further decrease the economic benefits of the process, it could be overcome by updating technology operations and maintenance to increase the production renewable energy during the process. Based on that, the integrated process had the potential to be an appropriate strategy to benefit the community by producing: healthy food (mushroom), clean energy, and organic fertilizer through the complete biomass circulation.

\section{Conclusions}

In this study, an integrated process as a small reusing system was set up and the full utilization of substances in rice straw was achieved. The biological efficiency of mushroom yield cultivated on rice straw was $40.1 \%$. During the AD process, the biomethane yield from SMS was $133.0 \mathrm{~L} / \mathrm{kg}$ VS. The fertilizer value of the digestate after $\mathrm{AD}$ was confirmed that in the range of the national standard of organic fertilizers in China. The integrated process also achieved a high utilization rate of nutritional compositions in rice straw. The potential of benefits generated during the process was appropriate for practical application. This study provides a significant strategy for full utilization of nutrients in rice straw.

\section{Acknowledgement}

The authors are grateful to the fund supports from National Key Technologies R \& D Program of China (2016YFD0501402).

\section{[References]}

[1] National Bureau of Statistics of China, 2017. China Statistical Year Book 2016. China Statistics Press, Beijing, China. (in Chinese)

[2] Kaur D, Bhardwaj N K, Lohchab R K. Prospects of rice straw as a raw material for paper making. Waste Management, 2017; 60: 127.

[3] Wang Y J, BI Y Y, Gao C Y. The assessment and utilization of straw resources in China. Journal of Integrative Agriculture, 2010; 9(12): 1807-1815.

[4] Renáta B, Zsuzsanna P, József K, Szabina L, Adrienn N, Melinda D, et al Characterisation of the large-scale production process of oyster mushroom (Pleurotus ostreatus) with the analysis of succession and spatial heterogeneity of lignocellulolytic enzyme activities. Fungal Biology, 2015; 119(12): 1354-1363.

[5] Karimi K, Taherzadeh M J. A critical review on analysis in pretreatment of lignocelluloses: Degree of polymerization, adsorption/desorption, and accessibility. Bioresource Technology, 2015; 203: 348-356.

[6] Kuijk S J A V, Sonnenberg A S M, Baars J J P, Hendriks W H, Cone J W. Fungal treated lignocellulosic biomass as ruminant feed ingredient: A review. Biotechnology Advances, 2015; 33(1): 191-202.

[7] Zhang R, Li X, Fadel J G. Oyster mushroom cultivation with rice and wheat straw. Bioresource Technology, 2002; 82(3): 277-284.

[8] Monlau F, Barakat A, Trably E, Dumas C, Steyer J P, Carrère H. Lignocellulosic materials into biohydrogen and biomethane: impact of structural features and pretreatment. Critical Reviews in Environmental Science and Technology, 2013; 2011(3): 260-322.

[9] Croce S, Wei Q, D'Imporzano G, Dong R, Adani F. Anaerobic digestion of straw and corn stover: The effect of biological process optimization and pre-treatment on total bio-methane yield and energy performance. Biotechnology Advances, 2016; 34(8): 1289-1304.

[10] He Y, Pang Y, Li X, Liu Y, Li R, Zheng M. Investigation on the changes of main compositions and extractives of rice straw pretreated with sodium hydroxide for biogas production. Energy \& Fuels, 2009; 23(4): 2220-2224. 
[11] Song Z L, Yag G H, Feng Y Z, Ren G X, Han X H. Pretreatment of rice straw by hydrogen peroxide for enhanced methane yield. Journal of Integrative Agriculture, 2013; 12(7): 1258-1266.

[12] Song Z L, Yang G H, Guo Y, Zhang T. Comparison of two chemical pretreatments of rice straw for biogas production by anaerobic digestion. Bioresources, 2012; 7(3): 3223-3236

[13] Li K, Liu R H, Chen S. A review of methane production from agricultural residues in China. Renewable \& Sustainable Energy Reviews, 2016; 54: $857-865$.

[14] Tambone F, Scaglia B, D'Imporzano G, Schievano A, Orzi V, Salati S, et al. Assessing amendment and fertilizing properties of digestates from anaerobic digestion through a comparative study with digested sludge and compost. Chemosphere, 2010; 81(5): 577-583.

[15] Massé D I, Croteau F, Masse L. The fate of crop nutrients during digestion of swine manure in psychrophilic anaerobic sequencing batch reactors. Bioresource Technology, 2007; 98(15): 2819-2823.

[16] Lou Z, Zhu J, Wang Z, Baig S A, Li F, Hu B, et al. Release characteristics and control of nitrogen, phosphate, organic matter from spent mushroom compost amended soil in a column experiment. Process Safety \& Environmental Protection, 2015; 98: 417-423.

[17] Lou Z, Sun Y, Bian S, Ali B S, Hu B, Xu X. Nutrient conservation during spent mushroom compost application using spent mushroom substrate derived biochar. Chemosphere, 2017; 169: 23-31.

[18] Li J, Kong C, Duan Q, Luo T, Mei Z, Lei Y. Mass flow and energy balance plus economic analysis of a full-scale biogas plant in the rice-wine-pig system. Bioresource Technology, 2015; 193: 62-67.

[19] Mustafa A M, Poulsen T G, Sheng K. Fungal pretreatment of rice straw with Pleurotus ostreatus and Trichoderma reesei to enhance methane production under solid-state anaerobic digestion. Applied Energy, 2016; 180: 661-671.

[20] Wan C, Li Y. Fungal pretreatment of lignocellulosic biomass. Biotechnology Advances, 2012; 30(6): 1447-1457.

[21] Rouches E, Herpoëlgimbert I, Steyer J P, Carrere H. Improvement of anaerobic degradation by white-rot fungi pretreatment of lignocellulosic biomass: A review. Renewable \& Sustainable Energy Reviews, 2016; 59: 179-198.

[22] Lin Y Q, Ge X M, Liu Z, Li Y B. Integration of Shiitake cultivation and solid-state anaerobic digestion for utilization of woody biomass. Bioresource Technology, 2015; 182: 128-135.

[23] Amirta R, Herawati E, Suwinarti W, Watanabe T, Fleischmann P, Kim K M, et al. Two-steps utilization of Shorea wood waste biomass for the production of oyster mushroom and biogas - a zero waste approach. Agriculture \& Agricultural Science Procedia, 2016; 9: 202-208.

[24] Buah J N, Puije G C V D, Bediako E A, Abole E A, Showemimo F. The growth and yield performance of oyster mushroom (Pleurotus ostreatus) on different substrates. Biotechnology, 2010; 9(3): 338-342.

[25] Ministry of Agriculture of the People's Republic of China. Agricultural Industry Standard of the People's Republic of China (NY 525-2012): Organic fertilizer. China Agriculture Press, 2012. (in Chinese)

[26] APHA AW. Standard Methods for the Examination of Water and Wastewater, 21st Edition. American Water Works Association, 1998; 130.

[27] Ma W, Duan S, Tan D, Cheng Z, Meng F, Yang L, et al. Reuse of concentrated cellulose wastewater: Microwave-assisted synthesis of organic fertilizer with water-retaining property. Journal of Environmental Chemical Engineering, 2015; 4(1): 511-515.

[28] Colavolpe M B, Albertó E. Cultivation requirements and substrate degradation of the edible mushroom Gymnopilus pampeanus-A novel species for mushroom cultivation. Scientia Horticulturae, 2014; 180(1082): 161-166.

[29] Mikiashvili N A, Isikhuemhen O S. Productivity and nutritional content of culinary-medicinal oyster mushroom Pleurotus ostreatus (Jacq.: Fr.) P. Kumm. (Agaricomycetideae) fruit bodies cultivated on substrates containing solid waste from anaerobic digested poultry litter. International Journal of Medicinal Mushrooms, 2009; 11(2): 207-213.

[30] Salehi M, Ebrahimi R, Maleki A, Ghasemi Mobtaker H. An assessment of energy modeling and input costs for greenhouse button mushroom production in Iran. Journal of Cleaner Production, 2014; 64 (Supplement C): $377-383$.

[31] Passos F, Ferrer I. Influence of hydrothermal pretreatment on microalgal biomass anaerobic digestion and bioenergy production. Water Research, 2015; 68: 364-373

[32] Xiao B, Qin Y, Zhang W, Wu J, Qiang H, Liu J, et al. Temperature-phased anaerobic digestion of food waste: A comparison with single-stage digestions based on performance and energy balance. Bioresource Technology, 2018; 249 (Supplement C): 826-834.

[33] Xiao B, Qin Y, Wu J, Chen H, Yu P, Liu J, et al. Comparison of single-stage and two-stage thermophilic anaerobic digestion of food waste: Performance, energy balance and reaction process. Energy Conversion and Management, 2018; 156 (Supplement C): 215-223.

[34] Li W, Guo J, Cheng H, Wang W, Dong R. Two-phase anaerobic digestion of municipal solid wastes enhanced by hydrothermal pretreatment: Viability, performance and microbial community evaluation. Applied Energy, 2017; 189 (Supplement C): 613-622.

[35] Gourdet C, Girault R, Berthault S, Richard M, Tosoni J, Pradel M. In quest of environmental hotspots of sewage sludge treatment combining anaerobic digestion and mechanical dewatering: A life cycle assessment approach. Journal of Cleaner Production, 2017; 143 (Supplement C): 1123-1136.

[36] Yang W, Guo F, Wan Z. Yield and size of oyster mushroom grown on rice/wheat straw basal substrate supplemented with cotton seed hull. Saudi Journal of Biological Sciences, 2013; 20(4): 333-338.

[37] Vieira F R. Optimization of substrate preparation for oyster mushroom (Pleurotus ostreatus) cultivation by studying different raw materials and substrate preparation conditions (composting: phases I and II). World Journal of Microbiology \& Biotechnology, 2016; 32(11): 190.

[38] Deepalakshmi K, Mirunalini S. Pleurotus ostreatus: An oyster mushroom with nutritional and medicinal properties. Journal of Biochemical Technology, 2014; 5(2): 718-726.

[39] Corrêa R C G, Brugnari T, Bracht A, Peralta R M, Ferreira I C F R. Biotechnological, nutritional and therapeutic uses of Pleurotus spp. (Oyster mushroom) related with its chemical composition: A review on the past decade findings. Trends in Food Science \& Technology, 2016; 50(6): 103-117.

[40] Lin Y, Ge X, Li Y. Solid-state anaerobic co-digestion of spent mushroom substrate with yard trimmings and wheat straw for biogas production. Bioresource Technology, 2014; 169(5): 468-474.

[41] Zhu J, Han M, Zhang G, Yang L. Co-digestion of spent mushroom substrate and corn stover for methane production via solid-state anaerobic digestion. Journal of Renewable \& Sustainable Energy, 2015; 7(2): 559-565.

[42] Ye J, Li D, Sun Y, Wang G, Yuan Z, Zhen F, et al. Improved biogas production from rice straw by co-digestion with kitchen waste and pig manure. Waste Management, 2013; 33(12): 2653-2658.

[43] Zhang H, Zhang P, Ye J, Wu Y, Fang W, Gou X, et al. Improvement of methane production from rice straw with rumen fluid pretreatment: A feasibility study. International Biodeterioration \& Biodegradation, 2016; 113 (Supplement C): 9-16.

[44] Feng X, Castillo M D P, Schnürer A. Fungal pretreatment of straw for enhanced biogas yield. Svenskt gastekniskt center, 2013.

[45] Wei Y F, Li X J, Yu L, Zou D X, Yuan H R. Mesophilic anaerobic co-digestion of cattle manure and corn stover with biological and chemical pretreatment. Bioresource Technology, 2015; 198(1): 431-436.

[46] Guan R L, Li X J, Wachemo A C, Yuan H R, Liu Y P, Zou D X, et al. Enhancing anaerobic digestion performance and degradation of lignocellulosic components of rice straw by combined biological and chemical pretreatment. Science of the Total Environment, 2018; s 637-638: 9-17.

[47] Loria E R, Sawyer J E. Extractable soil phosphorus and inorganic nitrogen following application of raw and anaerobically digested swine manure. Agronomy Journal, 2005; 97(3): 879-885.

[48] Bougnom B P, Niederkofler C, Knapp B A, Stimpfl E, Insam H. Residues from renewable energy production: Their value for fertilizing pastures. Biomass \& Bioenergy, 2012; 39(39): 290-295.

[49] Börjesson P, Berglund M. Environmental systems analysis of biogas systems-Part II: The environmental impact of replacing various reference systems. Biomass \& Bioenergy, 2007; 31(5): 326-344.

[50] Kataki S, Hazarika S, Baruah D C. Assessment of by-products of bioenergy systems (anaerobic digestion and gasification) as potential crop nutrient. Waste Management, 2017; 59: 102-117.

[51] Dai B 1, Guo X J, Yuan D H, Xu J M. Comparison of different pretreatments of rice straw substrate to improve biogas production. Waste and Biomass Valorization, 2018; 9(9): 1503-1512.

[52] Cragg S M, Beckham G T, Bruce N C, Bugg T D, Distel D L, Dupree P, et al. Lignocellulose degradation mechanisms across the tree of life. Current Opinion in Chemical Biology, 2015; 29: 108-119.

[53] Jönsson L J, Martín C. Pretreatment of lignocellulose: Formation of 
inhibitory by-products and strategies for minimizing their effects. Bioresource Technology, 2015; 199: 103-112.

[54] Hou H, Zhou J, Wang J, Du C, Yan B. Enhancement of laccase production by Pleurotus ostreatus and its use for the decolorization of anthraquinone dye. Process Biochemistry, 2004; 39(11): 1415-1419.

[55] Isikhuemhen O S, Mikiashvili N A, Kelkar V. Application of solid waste from anaerobic digestion of poultry litter in Agrocybe aegerita cultivation: mushroom production, lignocellulolytic enzymes activity and substrate utilization. Biodegradation, 2009; 20(3): 351-361.

[56] Taniguchi M, Suzuki H, Watanabe D, Sakai K, Hoshino K, Tanaka T. Evaluation of pretreatment with Pleurotus ostreatus for enzymatic hydrolysis of rice straw. Journal of Bioscience \& Bioengineering, 2005; 100(6): 637-643.

[57] Rouches E, Zhou S, Steyer J P, Carrere H. White rot fungi pretreatment of lignocellulosic biomass for anaerobic digestion: Impact of glucose supplementation. Process Biochemistry, 2016; 51(11): 1784-1792.

[58] Sindhu R, Binod P, Pandey A. Biological pretreatment of lignocellulosic biomass-an overview. Bioresource Technology, 2016; 199: 76-82.

[59] Barakat A, Monlau F, Steyer J P, Carrere H. Effect of lignin-derived and furan compounds found in lignocellulosic hydrolysates on biomethane production. Bioresource Technology, 2012; 104(1): 90-99.

[60] Komilis D P, Ham R K. The effect of lignin and sugars to the aerobic decomposition of solid wastes. Waste Management, 2003; 23(5): 419-423.

[61] Zhang H J, Itakura A, Matsuto T. Carbon and nutrient distributions between gas, solid, and liquid in anaerobic digestion facilities for various types of organic waste. Biosystems Engineering, 2012; 113(1): 11-21.

[62] Malayil S, Chanakya H N, Ashwath R. Biogas digester liquid-a nutrient supplement for mushroom cultivation. Environmental Nanotechnology Monitoring \& Management, 2016; 6: 24-31. 